\title{
The Impacts of Operational Risks in the Supply Chain of Construction Projects in Malaysia
}

\author{
Mumammad Saeed SHAHBAZ*, Muhammad Asif QURESHI, Samiullah SOHU, Manthar Ali KEERIO
}

\begin{abstract}
Construction glitches have become serious issues for Malaysian construction projects. The construction industry is one of the industries driven by supply chains and affected by interconnected risks. Any disruption happening anywhere will halt the whole project or even other projects. However, massive literature is available to deal with various kinds of risks from the supply chain (SC) of the construction industry that have never been discussed before. This is an empirical investigation and the data was collected through a questionnaire distributed to the construction industry through systemic probability sampling. Final and purified data was analyzed with Structural Equation Modelling through Smart PLS. A total of three types of risks were identified from literature namely supply side risks (SR), process side risks (PR) and demand side risks (DR). It has been found that supply side risks and demand side risks have significant negative effects on supply chain performance (SCP) while process side risks also have negative effects on supply chain performance but not significant. This study will help managers to understand how supply chain risks (SCR) affect the construction industry and what type of risks they should be more aware of. This study covers only operational side risks while future research can be on other risks. Furthermore, various approaches can be proposed for mitigation but there is also a need to verify these approaches for Malaysia.
\end{abstract}

Keywords: construction industry; operational risks; supply chain; supply chain performance

\section{INTRODUCTION}

The construction industry is currently facing various challenges globally. It has been found that the Saudi Arabian construction industry finished only $30 \%$ of projects within the planned time and the average time consumed was between $10 \%$ to $30 \%$ [1]. Nigeria, Thailand, Hong Kong, and Ghana have also recorded similar observations [2]. The Construction Sector is one of the most important sectors that contribute to Malaysia's economic growth. The sector accounted for nearly $3.5 \%$ of GDP in the year 2005 and employed about 600000 workers including 109000 foreign workers [3]. Meanwhile, literature has prescribed other disruptions in the Malaysian construction caused by supply chain disruptions $[2,4]$. The incompetence to accomplish supply chain disruptions and poor implementation of policies affect construction projects of Malaysia that prevent the management to achieve the competitiveness in budgeting [5]. Additionally, the unexpected increase in oil and gold prices and the taxes on goods and services by the federal government impact significantly Malaysian construction projects [6].

Risk or disruption of risk can be anytime, anywhere and to anyone but it does not mean to halt, life has to move on. Meanwhile, if someone has noteworthy planning or contingencies, the loss can be avoided, mitigated or minimized [7]. Supply chain (SC) is a flow of material, finance, and information. Currently, the supply chains are involved in every part of the business either directly or indirectly. The old term logistic was only responsible for the transfer of goods from supplier to the manufacturer and then to customers but now it is not a simple chain anymore, it has become a complex network [8]. Nowadays, supply chain and supply chain risks (SCR) have gained the interest of many researchers and practitioners [9]. Supply chain risk management is full of challenges that can result in higher costs, wasted materials, and production errors. It has become even more complex and vulnerable than it was in the past. In an investigation more than $60 \%$ of the companies revealed that their performance indicators had decreased by $3 \%$ or more due to supply chain disruptions [10].
It can be concluded that the construction sector is facing numerous challenges but most affecting factors are from the supply chain side. Based on the extensive literature review, it can be concluded that although there are plenty of studies available on the construction sector in Malaysia the studies that cover construction supply chains are scarce. This is a quantitative study that empirically verifies that the Malaysian construction sector needs to be aware of operation side risks, especially from the supply side and demand side risks. Data were collected from Malaysian construction projects by emails by systematic probabilistic sampling. After data screening, missing values, and outliers' analysis, validity and reliability have been evaluated through Smart PLS. This study may help managers of construction projects to be aware of potential risks related to supply chains.

\section{LITERATURE REVIEW}

This chapter will explain in detail the foundation of the study, the variables, and their relationship. First, independent variables will be discussed, the definitions and the details of supply chain risk management and risk sources. Secondly, performance will be elaborated highlighting its indicators and importance. Lastly, methodology, analysis, results, and discussion will be explained.

\subsection{Malaysian Construction Industry}

Malaysian Government formulated transformation programs in Vision 2020. The major segment of this vision is the "Tenth Malaysia Plan". Under this plan, RM138 billions are allocated for enhancement of the construction sector, comprising both private and public sector projects. However, despite the concerned ministries' and Government departments' proper plans the "Malaysian National Audit Department" highlighted various problems and disruptions in terms of implementation. Based on the report, construction organizations are poor in terms of stakeholders 'the management and team management, lacking in technical skills, lack of coordination in the 
supply chain, as well as various internal issues. Meanwhile literature has shown other disruptions in Malaysian projects due to problems in the supply chain as well $[2,4]$. The incapability to accomplish the disruptions in the supply chain and improper application of working mechanisms have negatively impact Malaysian projects as well [5]. Additionally, the unexpected acceleration in the prices of oil and the taxes has a significant effect on supply chain of Malaysian construction projects [1]. Construction industry's logic of collaboration can be observed by the parameter set by the team such as architects, managers, consultants and suppliers that contribute from the start of the projects till the end of the project [2]. Currently, the supply chain is only applied to the flow of materials and goods in the manufacturing industry, whilst the efficiency of the concept is also crucial to the construction sector in terms of the flow of construction materials and supplies of parts [11].

\subsection{Operational Risks}

Effective risk management can only be made possible if risks are properly identified, whether it is dealing with safety challenges, quality, supply shortages, regulatory and environmental compliance, legal issues, natural disasters, security problems, or terrorism. According to Jüttner, [13], sources of risks can be defined by unpredictable variation that can drive the disruption, and this study shows that risk sources are now more complex and modern, as supply chain has become more essential. Supply chain risk management can be categorised according to its risk sources [12]. It has been revealed that the main function of supply chain risk management (SCRM) is to identify the potential risk sources. Chen, [13], studied 90 articles on supply chain risk sources and concluded that $25 \%$ of articles have used only supply side risk, very few studies have applied disruption risks and the studies that covered all dimensions of risks were very limited in number. Moreover, [14] reviews and 138 articles found that less than $25 \%$ of articles have applied the quantitative technique in supply chain risk management. It can be concluded that the studies that cover operational side risks are scarce. The other name of supply chain risk is supply chain risk sources (SCRS). There are two types of SCRS internal risks also known as operational risks and external risks also known as disruption risks [19]. Internal risks are capacity problems, information issues and end-user problems etc. On the other hand, external risks are regarded as external economic issues, competition, political uncertainty, terrorism and natural disasters etc. [15]. This study has focused on operational or internal risks that are supply side risks, demand side risks, and operational risks.

\subsubsection{Supply Side Risks}

Supply side risks are the unplanned occurrence of any activity in the upstream of the supply chain that negatively affects the firm's capability to filling customer's demand whichever, collectively or individually [16]. Authors [17] described the supply side risks as very important as most of the research in supply chain disruption is on supply disruptions. In Supply, the risks start from supplier's supply to manufactures' manufacturing bases, in other words, it is called backward integration. According to [18] supply risks can be defined as "the potential occurrence of an incident associated with inbound supply from individual supplier to the supply market, in which its outcomes result in the inability of the purchasing firm to meet customer demands or cause threats to customers' life and safety". Toyota, a famous car manufacturer, had to shut down its manufacturing. It had to halt half of its assembling for around two months due to the fire in the plant of one supplier, so the supplier was unable to provide the supply on time [19]. Supply side risks can be because of the dependability of the supplier, moral risks, not compliance with the environment, purchasing decisions or security issues. These may be unexpected price fluctuation, quality problems, conflicts, inventory issues, delays, complexity, technological problems, etc. [20]. This study is limited to poor logistics performance of suppliers, suppliers' quality problems, suddenly becoming defaulter of a supplier, poor logistics performance of logistics service providers and capacity fluctuations or shortages on the supply markets [21].

Supply side risks originate from upstream or from supplier's side and include the disruptions in supply, price escalation, inventory, schedules, technological uncertainty, technological non-access, product complexity, quality issues or frequent changes in design [21]. It has been proved that supply side risks have a great negative impact on performance [22]. Meanwhile, in some studies, this relationship is not significant $[22,23]$. However, in light of this study, the researcher would conclude that any disruption in supply side not only affects manufactures but also affects end-users or customers [24].

H1: Supply side risks negatively affect supply chain performance.

\subsubsection{Process Side Risks}

Inadequate production is an essential part that can negatively affect performance of organization. Organizations can face not only financial disruptions but reputational as well [17]. Process risks can be defined as damage consequential from insufficient or failed in-house processes [25]. Internal process risk is defined as the probability of occurrence of an event related to the principal organization that may disturb the internal ability of that organization, either of producing goods or of services; disturbance may be related to quality or timing issues. Process risks are incompetence in the process, shortage of material, old technology etc. [26]. The aim of this research is to investigate the loss of own production capacity due to local disruptions that are fire, strikes, accidents, problems in the IT such as viruses in the computers or bugs in the software, damage in the production because of technical issues such as machine breakdown and breakdown of external IT [27].

Process side risks are derived from operations. "Any potential source that generates a negative impact on the flow of information, goods, and cash in our operations is an operational risk" [8]. It has been proved that operational or process risks negatively affect performance [22]. While in some studies the relationship is not significant [28].

$\mathrm{H}_{2}$ : Process side risks negatively affect supply chain performance. 


\subsubsection{Demand Side Risks}

Demand risks are commencing by the downside of supply chain [29]. Demand side risk is the chance of occurrence of an event related to outer flow toward customers such as wrong order placement from customers or change in order [30]. Demand side risks may be in the shapes of delays, laziness in the development of the new product, error in projections, fluctuations in demand, incorrect information. Industrial factors are market uncertainties, uncertainties in product markets, and uncertainty in competition. Lastly, organizational factors show some collective uncertainties like operations, research and development, credit, and behavioral uncertainties [31]. Paper [17] discloses that literature on demand fluctuation is very scarce. The demand risks are unpredictable demand or volatile demand and insufficient or distorted information from the customers about orders or demand quantity etc.

Disruptions derived from downstream of the supply chain, include disruptions in physical distribution, disruptions due to wrong information or forecasting and bad payments [32]. The study of [33] revealed that disruption from supply sides and demand sides is most dangerous for the business environment. It has been discovered that demand side risk negatively affects supply chain performance [23].

$\mathrm{H}_{3}$ : Demand side risks negatively affect supply chain performance.

\subsection{Supply Chain Performance}

The supply chain performance is "a set of metrics used to quantify the efficiency and effectiveness of supply chain processes and relationships, spanning multiple organizational functions and multiple firms and enabling supply chain orchestration" [34]. The goal of a firm is to increase the performance so the firm must measure performance accurately first [35]. Literature shows that in the past performance was being measured in terms of financial perspectives only such as cost; however with the development other indicators were added such as asset turnover, investment level [36]. Later on, it has been realized that only financial indicators are not enough; consequently, the balanced scorecard approach has been proposed and operational indicators have been introduced. Various other frameworks have also been incorporated to measuring performance such as quantitative or qualitative measures, tactical and strategic [37]. It has been found that all the members of the supply chain must be considered for performance measurement, as competition is no more among organizations but network. Therefore, a good performance measure must have some criteria such as financial and non-financial indicators should be considered. Meanwhile, all the levels of the supply chain must be included. Additionally, all processes of the supply chain must be incorporated.

Meanwhile, researchers have used many ways to examine the impact of supply chain risks and practices with various performances such as organizational performance or firm performance [37], product performance, operational performance [38, 39], logistic performance [40], financial performance [41] or supply chain performance $[3,25]$. Nevertheless, indicators to measure the above-mentioned performances are alike. Mostly used items of measurements are boosting up profit, reducing cost, customer satisfaction, reducing customer complaints, increasing service level, productivity improvement, decreasing lead time, enhance filling capacity, improving flexibility, reducing surplus and improving value. Details of each study are provided below.

Deciding on an appropriate combination of performance indicators for measuring supply chain performance is always challenging [42]. Performance measures should have some characteristics like sustainability, relevance, effectiveness, coherence, efficiency, and robustness [43]. In this study all the variables such as supply chain risks apply chain approaches to mitigate the risks and supply chain performance were adapted from different studies; this adapted work has used multiple ways to measure the performance according to the situation. This study adopts the indicators of performance measures from [13]. They are: order fill capacity, product quality, delivery speed, delivery dependability and customer satisfaction.

Table 1 Measurement items for supply chain performance

\begin{tabular}{|c|l|c|}
\hline \multirow{4}{*}{ Variable } & \multicolumn{1}{|c|}{ Items } & Reference \\
\hline \multirow{4}{*}{ Supply chain performance } & Quality & \multirow{4}{*}[23]{} \\
\cline { 2 - 2 } & Customer satisfaction & \\
\cline { 2 - 2 } & Order fill capacity & \\
\cline { 2 - 2 } & Delivery speed & \\
\cline { 2 - 2 } & Delivery dependability & \\
\hline
\end{tabular}

\subsection{Conceptual Framework}

After a sufficient review of the problem and previous studies, a framework was proposed. Fig. 1 illustrates the research framework that contains three independent variables such as supply, demand and process side risks, while a dependent variable is supply chain performance.

\begin{tabular}{|c|c|c|}
\hline Variable & & Items \\
\hline \multirow{10}{*}{$\begin{array}{l}\text { Supply } \\
\text { side } \\
\text { risks }\end{array}$} & SR1 & "Supplier's human resource problems" \\
\hline & SR2 & "Supplier quality problems" \\
\hline & SR3 & "The unexpected default of suppliers" \\
\hline & SR4 & "Frequent delays of suppliers" \\
\hline & SR5 & "Dependency on a single supplier for critical time" \\
\hline & SR6 & "Capacity fluctuations of suppliers" \\
\hline & SR7 & "Vague inspection procedures of the suppliers" \\
\hline & SR8 & $\begin{array}{l}\text { "Supplier locked (the i.e. company cannot easily } \\
\text { switch to another supplier)" }\end{array}$ \\
\hline & SR9 & "Unethical practices of suppliers revealed in public" \\
\hline & SR10 & "Nonavailability of technical expertise of suppliers" \\
\hline \multirow{5}{*}{$\begin{array}{c}\text { Process } \\
\text { side } \\
\text { risks }\end{array}$} & PR1 & "Frequent product recall process" \\
\hline & PR3 & "High labor turnover" \\
\hline & PR5 & "Vague inspection procedures" \\
\hline & PR6 & $\begin{array}{l}\text { "Improper handling/maintenance of strategic } \\
\text { warehouses/inventory" }\end{array}$ \\
\hline & PR9 & $\begin{array}{l}\text { "Loss of own production capacity due to technical } \\
\text { reasons (e.g. machine deterioration) " }\end{array}$ \\
\hline \multirow{8}{*}{$\begin{array}{l}\text { Demand } \\
\text { side } \\
\text { risks }\end{array}$} & DR1 & "Volatile customer demands" \\
\hline & DR2 & $\begin{array}{l}\text { "Customers change specifications (time, quality, } \\
\text { quantity)" }\end{array}$ \\
\hline & DR3 & "Large forecast errors in demand" \\
\hline & DR4 & "Frequent delays in delivery to customers" \\
\hline & DR5 & "Reputation risks" \\
\hline & DR7 & "Customers' dependency" \\
\hline & DR8 & $\begin{array}{l}\text { "Loss due to customers' faults (Any mistake from } \\
\text { the customer)" }\end{array}$ \\
\hline & DR9 & "Higher customer expectations" \\
\hline
\end{tabular}


Based on literature all three independent variables have a negative relationship. Fig. 1 is describing that risk sources have a negative relationship with supply chain performance as it has been verified in Australia, Germany, USA and many other countries with multiple approaches, some constructs significantly affect while others do not $[47-50]$.

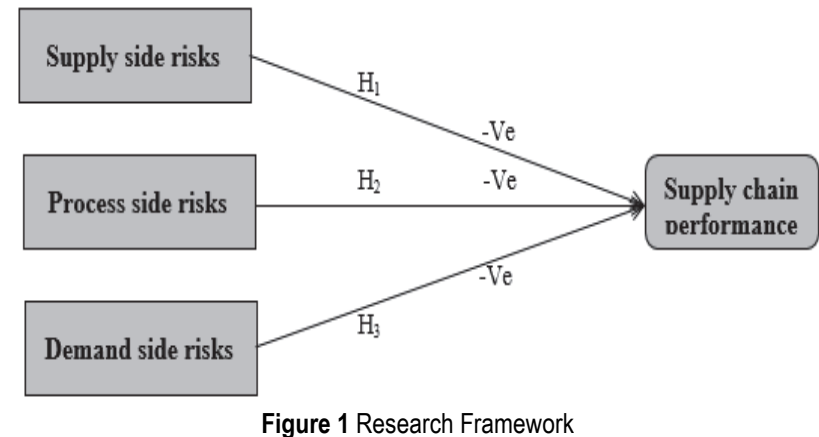

\section{METHODOLOGY}

The focus of this study is to know the effects of supply chain risks on supply chain performance and the aim of this study is to empirically verify the relationship between constructs. Therefore, this study gathers the experiences from humans in numbers thus this is an empirical quantitative study. The research philosophy is positivism, the research approach is cross-sectional and the research strategy is quantitative, while the purpose is to test the hypothesis and generalize the findings based on existing theory. A survey method has been used for data collection. Likert scale with 7 points has been used and questionnaires have been distributed through the internet by systematic probability sampling. The questionnaire has been adapted from various reputed studies based on extensive literature review; the details of the adopted items are mentioned in Tab. 2. The target population in this study consists of the supply chain of the construction industry. The samples of this study are all members of the organizations including distributors, retailers, and suppliers and customers. The questionnaires were distributed to the members through self-administered surveys by email. Four hundred and sixty-five (465) questionnaires were sent to the employees of listed construction companies in Bursa Malaysia and after two reminders, each at the one-month interval, a total of 247 responses were received. Data screening was applied to analyze the missing values and it was found that 11 responses were incomplete. Thus the missing values with no pattern were filled with average values. The remaining 236 purified responses were considered for final data analysis.

\section{ANALYSIS AND DISCUSSION}

The purpose of this research is to examine the relationship between operational risks and supply chain performance for the Malaysian construction industry. Data were analyzed through SPSS and Smart PLS. First, the special codes were assigned to all items and data was put in the SPSS file. The second step was a manual screening of data, responses with high missing values and the same responses have been deleted. Furthermore, by histogram and skewness and kurtosis, data has been cleaned from missing values and outliers. The validity and reliability of the questionnaire have been assessed and lastly, the structural model has been evaluated by multiple regressions through Smart PLS.

\subsection{Demography of the Study}

The respondents for this study possessed all levels of management like strategic level, operational level and tactical level of construction supply chain as only they have been considered as the people relevant to the strategic implications for organizations. Fig. 2 shows the respondents managerial level with respect to experience in years.

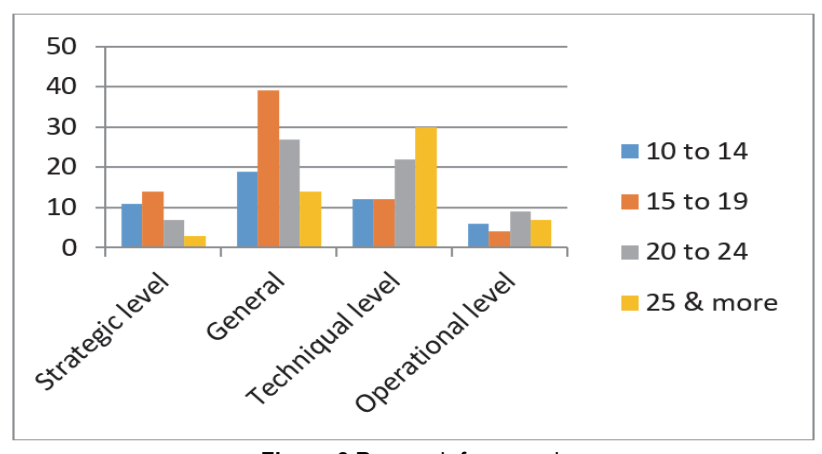

Figure 2 Research framework

\subsection{Measurement Model}

Reliability and validity are crucial for the quality of research in the quantitative approach of social sciences research [44]. This study calculated composite reliability, convergent validity, and discriminant validity to verify the measurement model. Smart PLS 3 has been used for reliability and validity. Fig. 3 shows the PLS Algorithm results for a direct relationship while Fig. 4 illustrates the PLS bootstrapping for the direct model. The range of composite reliability is between zero (0) and one (1), it means the greater the values the greater the reliability. However, the threshold limit considers acceptable at greater than 0.70. Composite reliability should be lower than 0.60 , which shows insufficiency of internal consistency. If the value of composite reliability is greater than 0.90 , as it reflects that all the items are measuring the same phenomenon, it is not required [45-46]. An AVE value of 0.50 or higher indicates that the construct explains more than half of the variance of its indicators, while an AVE of less than 0.50 indicates that more error remains in the items than the variance explained by the construct [45]. Generally, the convergent validity of the values of factor loading [47]. If factor loading is very high that shows convergence for a latent construct. A rule of thumb for factor loading is that it should be at least 0.5 or higher. However, 0.7 or greater is considered good. Average factor loadings should be statistically significant, [47]. Fornell \& Larcker criteria mean to compare the AVEs for each construct with the square of the estimated correlation between these constructs [47]. It has been revealed that most of the researchers prefer Fornell \& Larcker criteria and look at it as a conservative approach [48]. It compares the square root of the AVE values with the latent variable 
correlations. Specifically, the square root of each construct's AVE should be greater than its highest correlation with any other construct. Fig. 3 and Fig. 4 explain that all the values are meeting the threshold criteria. Thus, the instrument is validated and is reliable.

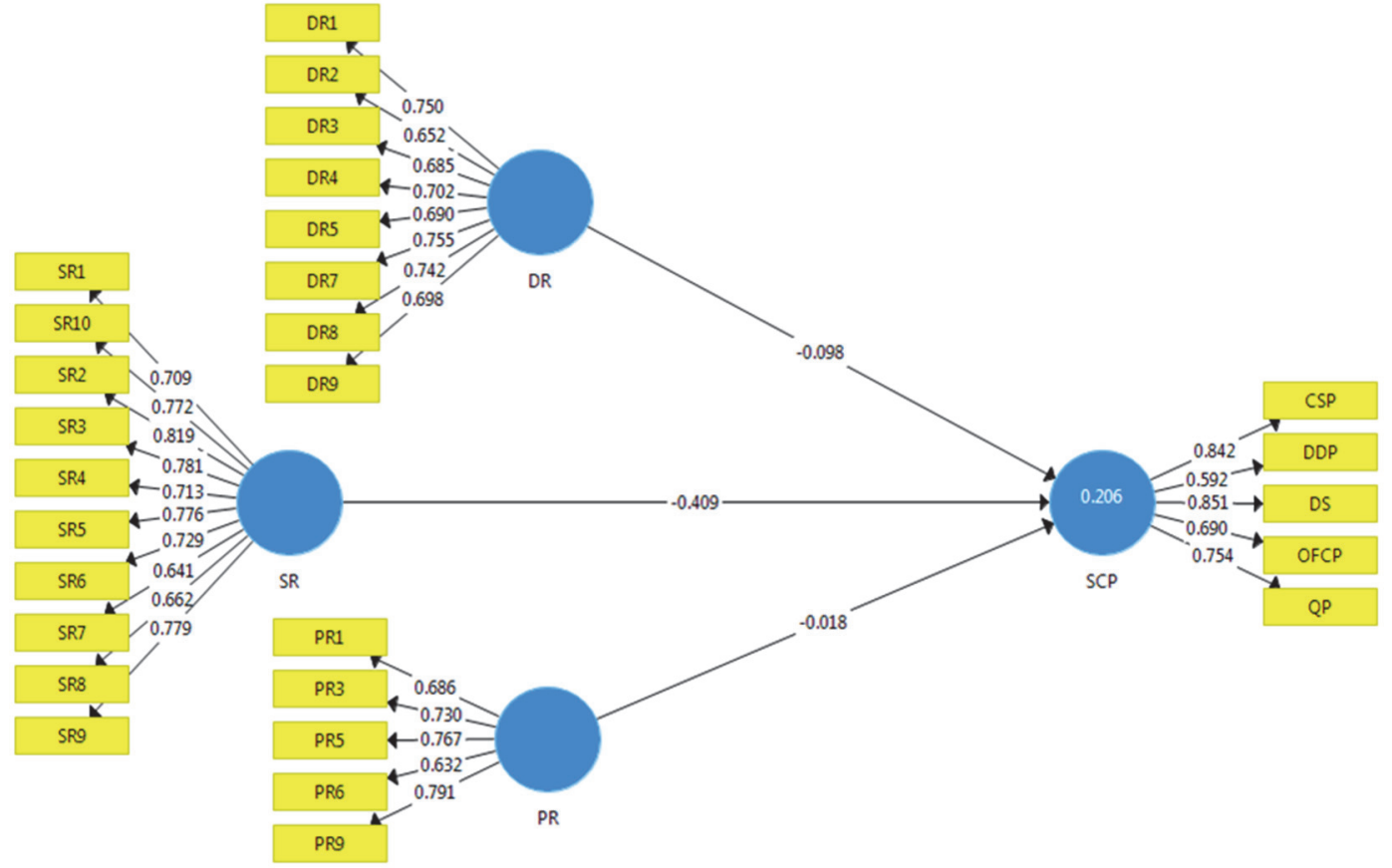

Figure 3 PLS Algorithm

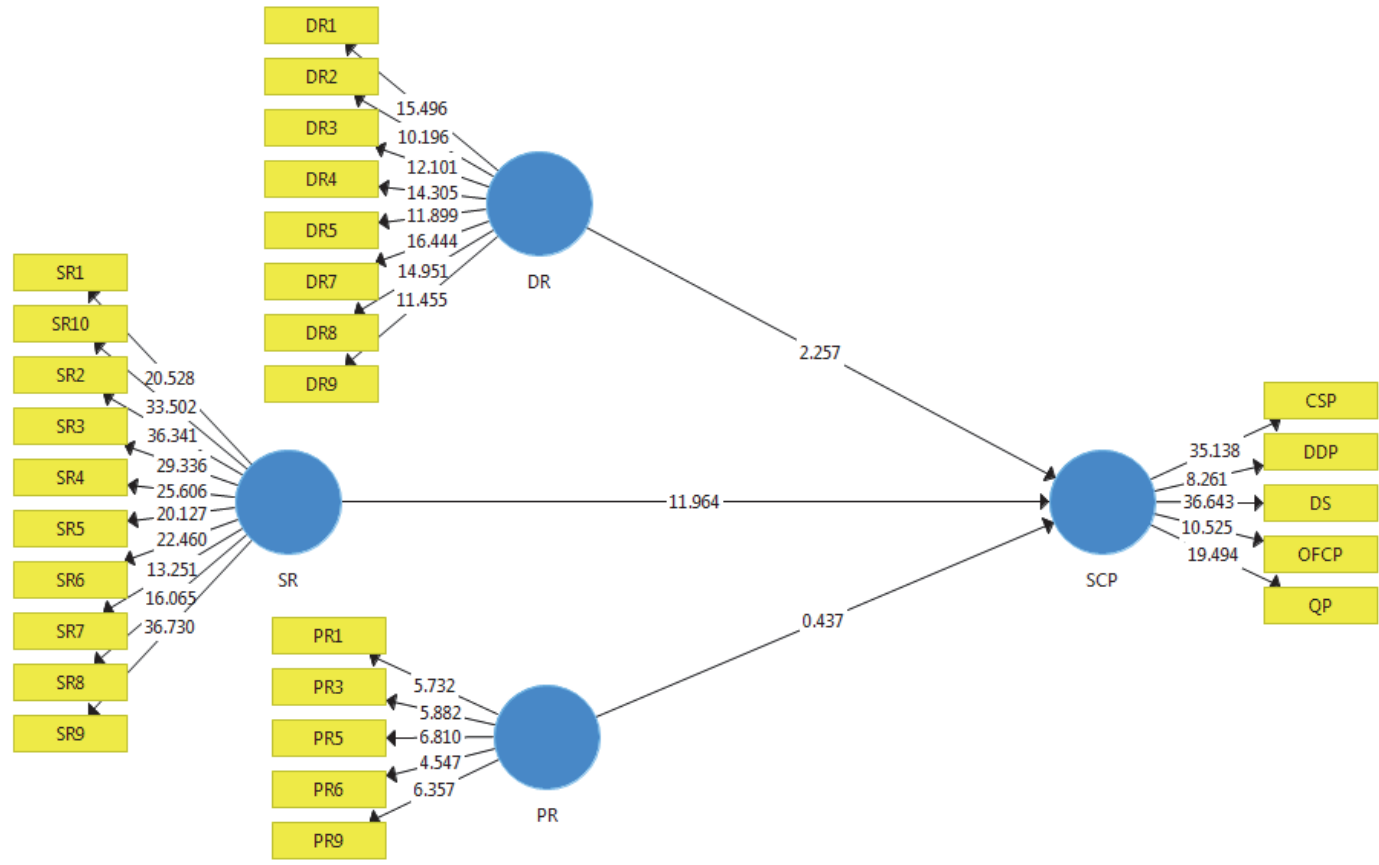

Figure 4 PLS bootstrapping for direct model

Table 3 Validity and reliability

\begin{tabular}{|l|c|c|c|c|}
\hline \multicolumn{1}{|c|}{ Constructs } & Number of items & Cronbach's $\alpha$ & Composite reliability & Average variance extracted \\
\hline Supply side risks & 10 & 0.908 & 0.923 & 0.548 \\
\hline Process side risks & 5 & 0.782 & 0.845 & 0.523 \\
\hline Demand side risks & 8 & 0.863 & 0.890 & 0.504 \\
\hline Supply chain performance & 5 & 0.830 & 0.865 & 0.565 \\
\hline
\end{tabular}

Table 4 Discriminant validity

\begin{tabular}{|c|c|c|c|c|}
\hline & SR & PR & DR & SCP \\
\hline SR & 0.740 & & & \\
\hline PR & 0.278 & 0.723 & & \\
\hline DR & 0.296 & 0.174 & 0.710 & \\
\hline SCP & -0.443 & -0.149 & -0.222 & 0.752 \\
\hline
\end{tabular}

\subsection{Structural Model}

This study has applied Smart PLS to the examined coefficient of determination $R^{2}$, standardized path (Beta coefficient) and $t$-statistics. A standardized path value shows the strength of the relationship if the value is 
negative which shows the negative relationship between the variables and vice versa. The statistical level of the $t$ value shows the significant level of a relationship. This study chose a $10 \%$ level of significance as this is predictive study so chances of error are high. Lastly, $R^{2}$ examines the effect of independent variables on dependent variables. Meanwhile, both independent and moderator variables are continuous variables so interaction terms were calculated from standardized values to avoid collinearity problems.

The aim of this study was to evaluate the effects of SR, PR, and DR on SCP. This effect is calculated by the coefficient of determination $R^{2}$. "R $R^{2}$ is a measure of the proportion of an endogenous construct's variance that is explained by its predictor constructs". Fig. 3 this study applies PLS and found that $R^{2}$ is 0.206 or $20.6 \%$. The low value of $R^{2}$ is not surprising as it is consistent with previous studies and it has been learned in the literature review that supply chain performance is dependent on numerous factors besides supply chain risks $[22,33]$.

Meanwhile, standardized path coefficients and their tstatistics were obtained from PLS analysis for making a decision regarding the hypothesis. The path coefficient was generated by using the algorithm, while the standard errors were computed by using the bootstrap resampling method with 500 resamples. Tab. 5 shows that all three operational risks have negative effects of supply chain performance but only two risk sources namely supply side risks $(\beta=-0.409$, $t=11.561, p<0.05)$, and demand side risks $(\beta=-0.098, t$ $=2.160, p<0.05)$ are significantly affecting. On the other hand, process side risk $(\beta=-0.018, t=0.412, p<0.05)$ is not significantly affecting supply chain performance. Thus, it can be concluded that two hypotheses H1, H3 are accepted, while $\mathrm{H} 2$ is rejected at a $5 \%$ level of significance. It can be concluded that the Malaysian construction industry has major risks from its supply side and more specifically from supplier and customer sides.

Table 5 Structural relationship

\begin{tabular}{|c|c|c|c|c|}
\hline Hypothesis & Paths & $(p$-Values $)$ & $t$-values & Decision \\
\hline H1 & $\mathrm{SR} \rightarrow \mathrm{SCP}$ & -0.409 & 11.561 & Accepted \\
\hline $\mathrm{H} 2$ & $\mathrm{PR} \rightarrow \mathrm{SCP}$ & -0.018 & 0.412 & Rejected \\
\hline $\mathrm{H} 3$ & $\mathrm{DR} \rightarrow \mathrm{SCP}$ & -0.098 & 2.160 & Accepted \\
\hline
\end{tabular}

\section{CONCLUSION}

This is an empirical verification so a questionnaire has been developed by adapted items; data have been collected from construction supply chain organizations. Data have been analyzed through SPSS and Smart PLS. Manual screening, missing values, outliers, correlation, multiple regression, have all been calculated. Finally, it can be concluded that the Malaysian construction industry is risky in terms of supply side risks and demand side risks. This study identified 10 types of risks from the supplier side, 5 types of risks from the process side and eight types of risks from demand side after the systemic process. Supply side risks and demand side risks are considered dangerous for the construction industry as they have significant negative effects on supply chain performance. Based on the findings of this study the managers will have a better understanding of the Malaysian manufacturing industry being in a dangerous situation and also of ways to deal with this dangerous situation. Future research can explore disruption risks and network risks. The research gap for future studies is to propose a mitigation strategy to deal with operational risks.

\section{REFERENCES}

[1] Shahbaz, M. S., Soomro, M. A., Bhatti, N. U. K., Soomro, Z., \& Jamali, M. Z. (2019). The Impact of Supply Chain Capabilities on Logistic Efficiency for the Construction Projects. Civ. Eng. J., 5(6), 1249-125. https://doi.org/10.28991/cej-2019-03091329

[2] Abidin, N. A. Z. (2018). Resilience Of Malaysian Public Sector Construction Industry To Supply Chain Disruptions. University of Huddersfield: Ph.D. Thesis.

[3] Ahmad , N. \& Saifudin, A. M. (2014). Supply Chain Management in Telecommunication Industry: The Mediating Role of Logistics Integration. ICTOM 04-4th Int. Conf. Technol. Oper. Manag. Supply, 648-653.

[4] Riazi, S. R. M., Skitmore, M., \& Cheung, Y. K. F. (2011). The use of supply chain management to reduce delays: Malaysian public sector construction projects. 6th Nord. Conf. Constr. Econ. Organ. Soc., Copenhagen, Denmark, 403-414.

[5] Hardy, B. \& Ford, L. R. (2014). It's Not Me, It's You: Miscomprehension in Surveys. Organ. Res. Methods, 17(2), 138-162. https://doi.org/10.1177/1094428113520185

[6] Shahbaz, M. S., Chandio, A. F., Oad, M., Ahmed, A., \& Ullah, R. (2018). Stakeholders ' Management Approaches in Construction Supply Chain: a New Perspective of Stakeholder' S Theory. Int. J. Sustain. Constr. Eng. Technol., 9(2), 16-26. https://doi.org/10.30880/ijscet.2018.09.02.002

[7] Zandhessami, H. \& Savoji, A. (2011). Risk management in supply chain management. Int. J. Econ. Manag. Sci., 1(3), 60-72.

[8] Kouvelis, P., Dong, L., Boyabatli, O., \& Li, R. (2012). Handbook of Integrated Risk Management in Global Supply Chains. New Jersey: Wiley. 1-605. https://doi.org/10.1002/9781118115800.ch1

[9] Zubair, M. \& Mufti, N. A. (2015). Identification and Assessment of Supply Chain Risks Associated with Dairy Products Sector. J. Basic Appl. Sci., 11, 167-175. https://doi.org/10.6000/1927-5129.2015.11.25

[10] PWC\&MIT. Supply Chain Innovation-strengthen operations performance, Report, 2013.

[11] Tazehzadeh, M. N. (2014). Investigation of Supply Chain Risk Management Implementation in Canadian Construction Industry. Eastern Mediterranean University: Master Thesis.

[12] Colicchia, C. \& Strozzi, F. (2012). Supply chain risk management: a new methodology for a systematic literature review. Supply Chain Manag. An Int. J., 17(4), 403-418. https://doi.org/10.1108/13598541211246558

[13] Chen, J., Sohal, A. S., \& Prajogo, D. I. (2013). Supply chain operational risk mitigation: A collaborative approach. Int. J. Prod. Res., 51(7), 2186-2199. https://doi.org/10.1080/00207543.2012.727490

[14] Musa, S.N. (2012). Supply Chain Risk Management: Identification, Evaluation and Mitigation Techniques. Linköping University Sweden: Ph.D. Thesis.

[15] Buscher, S. A. \& Ayuso, A. P. (2015). Factors Influencing Tier 2 Supply Chain Risk Data Collection. Massachusetts Institute of Technology.

[16] Rajabinasr, A., Nourbakhshian, M., \& Hooman, A. (2013). The Main Tools Used in Supply Chain Risk Management. Interdiscip. J. Contemp. Res. Bus., 4(9), 968-975.

[17] Paul, S. K., Sarker, R., \& Essam, D. (2016). Managing risk and disruption in production-inventory and supply chain systems: A review. J. Ind. Manag. Optim., 12(3), 1009-1029. https://doi.org/10.3934/jimo.2016.12.1009 
[18] Balakrishnan, K. K. \& Nadarajah, G. (2016). Internal Process Risk Management: A Proposed Conceptual Framework for Electronic Design Industry Process Gap. Int. J. Supply Chain Manag., 5(4), 68-77.

[19] Jüttner, U. \& Maklan, S. (2011). Supply chain resilience in the global financial crisis: An empirical study. Supply Chain Manag. An Int. J., 16(4), 246-259. https://doi.org/10.1108/13598541111139062

[20] Prakash, S., Soni, G., Rathore, A. P. S., \& Singh, S. (2017). Risk analysis and mitigation for perishable food supply chain: a case of dairy industry. Benchmarking An Int. J., 24(1), 2-23. https://doi.org/10.1108/BIJ-07-2015-0070

[21] Basole, R. C., Bellamy, M. A., Park, H., \& Putrevu, J. (2016), Computational Analysis and Visualization of Global Supply Network Risks. IEEE Trans. Ind. Informatics, 12(3), 1206-1213. https://doi.org/10.1109/TII.2016.2549268

[22] Zsidisin, G. A., Petkova, B. N., \& Dam, L. (2015). Examining the influence of supply chain glitches on shareholder wealth: does the reason matter?. Int. J. Prod. Res., 10, 1-14. https://doi.org/10.1080/00207543.2015.1015751

[23] Chen, J. (2012). The Role of Supply Chain Collaboration in Supply Chain Risk Mitigation. Monash University: Ph.D. Thesis.

[24] Zhao, L., Huo, B., Sun, L., \& Zhao, X. (2013). The impact of supply chain risk on supply chain integration and company performance: a global investigation. Supply Chain Manag. An Int. J., 18(2), 115-131. https://doi.org/10.1108/13598541311318773

[25] Sundram, V. P. K., Chandran, V., \& Bhatti, M. A. (2016). Supply chain practices and performance: the indirect effects of supply chain integration. Benchmarking An Int. J., 23(6), 1445-1471. https://doi.org/10.1108/BIJ-03-2015-0023

[26] Shahbaz, M. S., Rasi, R. Z. R. M., Bin Ahmad, M. F., \& Rehman, F. (2017). What is supply chain risk management? A review. Adv. Sci. Lett., 23(9), 9233-9238. https://doi.org/10.1166/asl.2017.10061

[27] Shahbaz, M. S., Kazi, S., Bhatti, N. U. K., Abbasi, S. A., \& Rasi, R. Z. R. (2019). The Impact of Supply Chain Risks on Supply Chain Performance: Empirical Evidence from the Manufacturing of Malaysia. Int. J. Adv. Appl. Sci., 6(9), 112. https://doi.org/10.21833/ijaas.2019.09.001

[28] Tse, Y. K., Matthews, R. L., Hua Tan, K., Sato, Y., \& Pongpanich, C. (2016). Unlocking supply chain disruption risk within the Thai beverage industry. Ind. Manag. Data Syst., 116(1), 21-42. https://doi.org/10.1108/IMDS-03-2015-0108

[29] Wang, M. (2018). Impacts of supply chain uncertainty and risk on the logistics performance. Asia Pacific J. Mark. Logist., 30(3), 689-704. https://doi.org/10.1108/APJML-04-2017-0065

[30] Chopra, S. \& Meindl, P. (2016). Supply Chain Management: Strategy, Planning, and Operations (Global Edition), 6 TH. Harlow, England: Pearson.

[31] Wisner, J. D., Tan, K.-C., \& Leong, G. K. (2015). Principles of Supply Chain Management: A Balanced Approach, 43.

[32] Zsidisin, G. A. \& Ritchie, B. (2009). Supply chain risk: a handbook of assessment, management, and performance. New York: Springer: 156-157. https://doi.org/10.1007/978-0-387-79934-6

[33] Shahbaz, M. S., Rasi, R. Z. R. M., Zulfakar, M. H., Bin Ahmad, M. F., \& Asad, M. M. (2018). Theoretical Framework Development for Supply Chain Risk Management for Malaysian Manufacturing. Int. J. Supply Chain Manag., 7(6), 325-338.

[34] Maestrini, V., Luzzini, D., Maccarrone, P., \& Caniato, F. (2017). Supply Chain Performance Measurement Systems: A Systematic Review and Research Agenda. Int. J. Prod. Econ., 183(2015), 299-315. https://doi.org/10.1016/j.jpe.2016.11.005

[35] Shukla, R. K. (2016). Coordination Practices in Supply
Chain Management: An Empirical Study of Indian Manufacturing Firms. J. Manag. Res., 16(1), 44-54.

[36] Shahbaz, M. S., Rasi, R. Z. R. M., Zulfakar, M. H., Bin Ahmad, M. F., Abbas, Z., \& Mubarak, M. F. (2018). A Novel Metric of Measuring Performance for Supply Chain Risk Management: Drawbacks and Qualities of Good Performance. J. Fundam. Appl. Sci., 10(3S), 967-988.

[37] Shukla, R. K., Garg, D., \& Agarwal, A. (2013). Supply Chain Coordination Competency and Firm Performance : An Empirical Study. Int. J. Supply Chain Manag., 2(4), 64-70.

[38] Sukati, I., Hamid, A. B., \& Baharun, R. (2013). Testing the Effect of the Supply Chain Management Implementation on Business Performance: An Empirical Study. Int. Bus. Res., 6(1), 76-89. https://doi.org/10.5539/ibr.v6n1p76

[39] Kauppi, K., Longoni, A., Caniato, F., \& Kuula, M. (2016). Managing country disruption risks and improving operational performance: risk management along integrated supply chains. Int. J. Prod. Econ., 182, 484-495. https://doi.org/10.1016/j.ijpe.2016.10.006

[40] Effendi, F. S. R. (2015). The Determinants of Logistics Efficiency in Malaysia. Soc. Sci. Res. Netw.

[41] Fan, G. Li, H., Lee, P. K. C., \& Cheng, T. C. E. (2015). Joint supply chain risk management: An agency and collaboration perspective. Int. J. Prod. Econ., 164, 83-94. https://doi.org/10.1016/j.ijpe.2015.02.021

[42] Anand, N. \& Grover, N. (2015). Measuring retail supply chain performance: Theoretical model using key performance indicators (KPIs). Benchmarking An Int. J., 22(1), 135-166. https://doi.org/10.1108/BIJ-05-2012-0034

[43] Chardine-Baumann, E. \& Botta-Genoulaz, V. (2014). A framework for sustainable performance assessment of supply chain management practices. Comput. Ind. Eng., 76(1), 138-147. https://doi.org/10.1016/j.cie.2014.07.029

[44] Saunders, M., Lewis, P., \& Thornhill, A. (2016). Research Methods For Business Students, Seventh., vol. Seven. Essex: Pearson Education Limited. 1-741.

[45] Hair, J. F. J., Hult, G. T. M., Ringle, C. M., \& Sarstedt, M. (2014). A Primer on Partial Least Squares Structural Equation Modeling (PLS-SEM). United States of America: SAGE Publications. 1-329.

[46] Shahbaz, M. S., Rasi, R. Z. R. M., Bin Ahmad, M. F., Sohu, S. (2018). The impact of supply chain collaboration on operational performance: Empirical evidence from manufacturing of Malaysia. Int. J. Adv. Appl. Sci., 5(8), 6471. https://doi.org/10.21833/ijaas.2018.08.009

[47] Hair, J. F., Black, W. C., Babin, B. J., Anderson, R. E. (2014). Multivariate Data Analysis, Seventh Ed. United States of America: Pearson Education Limited. 1-739.

[48] Henseler, J., Ringle, C. M., \& Sarstedt, M. (2014). A new criterion for assessing discriminant validity in variancebased structural equation modeling. J. Acad. Mark. Sci., 43(1), 115-135. https://doi.org/10.1007/s11747-014-0403-8

\section{Contact information:}

Muhammad Saeed SHAHBAZ, Assistant Professor

(Corresponding author)

Shaheed Zulfikar Ali Bhutto Institute of Science and Technology,

Pakistan

E-mail: msaeed.shahbaz@gmail.com

\section{Muhammad Asif QURESH}

E-mail: qureshimuhammadasif@gmail.com

\section{Samiullah SOHU}

E-mail: sohoosamiullah@gmail.com

\section{Manthar Ali KEERIO}

E-mail: mantharali99@quest.edu.pk 